Sign Systems Studies 30.1, 2002

\title{
Tractatus Hoffmeyerensis: Biosemiotics as expressed in 22 basic hypotheses
}

\author{
Frederik Stjernfelt \\ Department of Comparative Literature, University of Copenhagen \\ Njalsgade 80A, 2300 Copenhagen, Denmark \\ e-mail: stjern@hum.ku.dk
}

\begin{abstract}
This paper briefly outlines the main ideas of biosemiotics in 22 hypotheses, with special regards to the version of it claimed by Jesper Hoffmeyer.
\end{abstract}

In honour of T. Sebeok (1920-2001)

In this paper, ${ }^{1}$ I shall attempt to summarize the basic ideas of the nascent science of biosemiotics in 22 brief statements. Generally, it is based on ideas circulating in the biosemiotic community, ${ }^{2}$ but with special reference to the version developed by the biochemist and semiotician Jesper Hoffmeyer, the founder of the Copenhagen school of biosemiotics. Still, the position presented here does not hesitate to draw conclusions and involve corollaries not explicitly stated by Hoffmeyer, in which he might not agree. In so far, the hypotheses are the author's responsibility - they should be seen as a vademecum of a Hoffmeyerian biosemiotics, according to me.

1) Signs and life are coextensive. ${ }^{3}$

\footnotetext{
${ }^{1}$ The article is a tribute to Jesper Hoffmeyer's 60th birthday February 21st 2002.

${ }^{2}$ On the history of biosemiotics, see Kull 1999.

${ }^{3}$ This idea is of course the core idea of biosemiotics and has been forcefully claimed by Thomas Sebeok, cf. e.g. “... semiosis is at the heart of life ..." (Sebeok
} 
2) As biology is a historical science (maybe even the historical science par excellence), (1) calls for a natural history of meaning ${ }^{4}$.

3) As biology is a structural science (maybe even the structural science par excellence), (1) calls for an inventory of biology's structural concepts. ${ }^{5}$

4) If we accept punctuated equilibrium as a basic structure in biological evolution, ${ }^{6}$ we should expect the semiotic evolution to follow the same structure, hence displaying a ladder of increasingly complex sign types.

5) The basic forms of biological signs are those exchanged between the organism and its environment, its Umwelt, in an Uexküll functional circle, Wirkzeichen and Merkzeichen respectively. ${ }^{7}$

6) The umwelt, in sufficiently complex life forms, is not genetically determined through and through, but must be formed in the individual case selecting paths in its own chreod landscape under impression of the interaction with the particular surroundings. ${ }^{8}$

7) Such an experience-based umwelt makes possible genetic assimilation (Waddington), because individuals with better genetic bases for coping with the particular surroundings will have a selection advantage. This so-called Baldwin effect will be especially efficacious in social animals where one individual may learn such umwelt competences from others. ${ }^{9}$ Thus the species' virtual reality as represented by its umwelt's set of inner representations of typical, merely potential

1991: 85), "semiosis is the criterial attribute of life" (Sebeok 1991a: 124), or "semiosis presupposes life" (Sebeok 2001).

${ }^{4}$ Hoffmeyer draws this conclusion in his 1992 and takes it further in his 2001b.

5 Biology thus forms a crucial part of the "structural ontology" claimed by Jean Petitot (e.g., 1992). I have myself (1999) tried to sketch a network of those concepts.

${ }^{6}$ This premiss rests, of course, upon Stephen Jay Gould's concept of punctuated equilibrium (Gould 1972).

${ }^{7}$ This idea in Uexküll $(1928,1982)$ has formed a core idea in biosemiotics and is widely discussed in a special issue of Semiotica (ed. K. Kull), 134(1/4) (2001), including Hoffmeyer 2001.

${ }^{8}$ Hoffmeyer gives this idea in (2001: 388) in a Waddingtonian conceptual apparatus: the Umwelt is taken to be constructed ontogenetically in a chreod of branching possibilities formally analogous and correlated to that proposed by Waddington to explain the epigenesis of the organism.

${ }^{9}$ The Baldwin effect is nicknamed after the American psychologist J. M. Baldwin (1902) who pointed out such a non-Lamarckian mechanism for inheritance of acquired properties. Deacon (1997) takes up the idea and applies it to the proposed co-evolution of language and brain in early hominids. 
relations in the organism's surroundings, may become genetic reality - "only the well-prepared will profit from chance". ${ }^{10}$

8) Generally, any new such habit taken exposes the organism to new challenges in a never-ending chain of interpretations. ${ }^{11}$

9) The role of selection remains decisive, but basic biological phenomena like multiplication ${ }^{12}$ as well as order ${ }^{13}$ are prerequisites to selection and hence cannot be products of it. Multiplication and order are inherently meaningful.

10) Both are thus more primitive than genes and pertain to the analogous side of the organism's double code (which is a not so lucky expression as only the former of them is really, strictly speaking, a code): digital, genetic information on the one hand, and analogical, morphological information on the other, provided by the cell's architecture and metabolism as well as multicellular structure and communication. ${ }^{14}$

11) Another prerequisite to the functional circle is organism's character as an agency equipped with a point-of-view. This may be defined as a "stable integration of self-reference and other-reference" 15 (the former maintaining and defining the self as such; the latter facilitating its orientation and survival in its umwelt).

12) Agency presupposes, in turn, the existence of an inside-outside defining boundary, a membrane, characterizing all life forms (except for certain marginal parasite types like virus). Membranes thus make possible the crucial organism-environment asymmetry - facilitating the constrained traffic across the membrane boundary in the form of signs. ${ }^{16}$ Autocatalytic closure of chemical reaction loops in the primordial soup ${ }^{17}$ thus needs a further topological membrane closing in order to result in organisms. The controlled traffic across the membrane permits the emergence of strictly constrained "inner outsides" (due to perception in a broad sense of the word) in the organism as well as

${ }^{10}$ Hoffmeyer 2001; Pasteur's bonmot is quoted from p. 393.

${ }^{11}$ Hypothesis (8) is a slightly abbreviated Hoffmeyer quote (from 2001: 392).

${ }^{12}$ Hoffmeyer (1999: 332), referring to Rod Swenson (1999).

${ }^{13}$ The argument that self-organized order is logically anterior to selection is made by Kauffman, e.g. 2000.

${ }^{14}$ Hoffmeyer, Emmeche 1991.

${ }^{15}$ Hoffmeyer 1999: 332.

${ }^{16}$ Hoffmeyer 1999: 333-336; 1998; 2001.

${ }^{17}$ Kauffman 2000. 
"outer insides" (due to its interaction with and influence on specific aspects of the environment).

13) Such signs embed the organism in its ecological umwelt comprising other organisms with umwelten. A mutualism much more widespread than strict symbiosis ${ }^{18}$ thus forms what Uexküll calls "a natural symphony" of mutual communication between species as well as between them and their surroundings.

14) Such communication necessarily involves, for economy reasons, categorical perception. Slightly different phenomena are functionally perceived as being the same type. ${ }^{19}$ This is probably the lowest or simplest semiotic phenomenon, based on the differently shaped "active sites" on the outside of macromolecules, which may be recognized by these sites on other molecules. ${ }^{20}$ By the same token, other molecules with the same sites may "fool" the process in question. This is the biochemical foundation of biological indeterminacy or semiotic freedom, but it requires a cyclical teleological (functional, final, purposeful, metabolic, homeostatic, or whatever predicate you prefer) process in order to display its possibilities. ${ }^{21}$

15) Biology is thus impossible without the Aristotelian quartet of causes. $^{22}$ Final causes should not, however, be identified with purposes (which form a special subset of them), but should be identified as all processes which are attracted by a future state. ${ }^{23}$ Future states being general only (Peirce), final causes may make use of representation of such states by means of types.

16) As we only know rather complicated life forms (cells internally consisting of organelles which are probably formerly symbiotically living organisms), these primitive semiotic processes also characterize the cell's internal metabolism. ${ }^{24}$

${ }^{18}$ Hoffmeyer 1999: 123-125.

${ }^{19}$ Stjernfelt 2001.

${ }^{20}$ Prodi 1988, Stjernfelt 1992.

${ }^{21}$ Cf. the "metabolic" tradition in biology emphasizing the importance of cyclic metabolisms, running from Kant (organisms as circles on the causal chain), via Uexküll (functional circle) to Kauffman (metabolism defined by thermodynamic work cycles).

${ }^{22} \mathrm{Cf}$. the argument for the importance of the formal cause (cyclic formal causes including final causes) in Thom 1989.

${ }^{23}$ The idea is Peirce's, cf. Hoffmeyer 2002.

${ }^{24}$ Cf. Sebeok's neologism "endosemiotics". 
17) The role of the genes seems to be that of controlling epigenetic and metabolic processes in the organism (not that of creating or determining them through and through). This points to the fact that genes may be a special and successful example of a more general notion of "scaffolding", 25 that is, stabilization and channelling of (a segment of) metabolism. Other such scaffoldings could be cell architecture, organ structure, language, writing...

18) At the upper end of the natural history of meaning we find animals with central nervous systems which have taken the bases of meaning in categorical perception to form very complex semiotic abilities. The increasing indeterminacy — or, semiotic freedom ${ }^{26}$ can be expressed as the emergence of sign types increasingly loosened from their basis in particular sign tokens. Higher animals may not only recognize tokens as instantiation of types, they may make use of these types to symbolize, to reason, argue, use diagrams. Probably, the special human privilege is abstraction, making it possible for us to make explicit and contemplate such types, reasonings, diagrams with any particular token placed in brackets and thus facilitating control, experiment, and quick development of these signs. ${ }^{27}$

19) Biosemiotics thus assumes a distinction between the issue of signs and that of consciousness. Sign process are taken to be possible without consciousness, and as the existence of signs may be inferred from the external behaviour of a process, the establishment of qualia consciousness in a system has - not yet, that is - any methodology. It seems to be a tendency, though, that complex signification processes are increasingly facilitated by consciousness, maybe as a special type of neural scaffolding.

20) The interrelated web of biosemiotic concepts used here membrane, sign, active site, function, metabolism, organism, umwelt, niche, and so on - forms a regional ontology (Husserl) of biology and semiotics, ${ }^{28}$ and any biology, even the most would-be reductionist

\footnotetext{
${ }^{25}$ Hoffmeyer's notion, cf. Hoffmeyer 2001.

${ }^{26}$ Hoffmeyer uses both terms, cf. 1999: 338; 1992.

${ }^{27}$ Deacon (1997) sees symbols as the human semiotic privilege; Stjernfelt (2001) proposes a specific subclass of symbols: abstractions.

${ }^{28}$ The idea of regional ontologies is first proposed by Husserl in the 3rd Logical Investigation (1980). Barry Smith has taken this as a basis for a general "fallibilistic apriorism" finding the ontological foundations in all special empirical sciences (1996), and has made explicit aspects of the ontology of umwelt and niche concepts in general (1998a; 1998b; 2001).
} 
versions, must willy-nilly make use of some versions or other of them. ${ }^{29}$ Such concepts provide the structural inventory called for in (3).

21) Biosemiotics does not entail vitalism, as it does not suppose the existence of élan vital, unknown organic force fields or the like. Neither does it entail any kind of subjectivism or relativism; even if every single organism and species has got its own point-of-view, this does not entail scepticism as those points-of-view may be compared and evaluated. Rather, biosemiotics entails idealism in a certain use of the word - not referring to the world being created by a subject or anything of the kind, but referring to the reality of ideal objects (like those conceptual networks of (20)). A special kind of ideal object here deserves mentioning, that of possibilities. Possibilities must assumed to possess real existence, including the idea of a fitness space of all possible genomes, ${ }^{30}$ the idea of virtuality in nature, ${ }^{31}$ the idea of tendencies in development and evolution, and, correlatively, the possibility for final causes to prefer one tendency over another. Thus, biosemiotics entails an ontological revolution admitting the indispensable role of ideality in this strict sense in the sciences.

22) To close the biosemiotic circle: real possibilities are also what make signs possible: any sufficiently complicated sign refers to a

${ }^{29}$ This goes against the argument of Tønnessen (2001) which claims that universal concepts of biology is impossible, because we could imagine forms of life completely different from the ones we know. This fallacy is so widespread that it must be countered here. It has exactly the same form as the argument against cultural universals: "we could imagine cultures which were completely different from ours". The fault lies in the word "completely": if a thing differs completely from another, we do not know anything about it at all. Consequently, we do not know if it is a life form, a culture, or something else. The argument thus boils down to the idea that we can imagine something that we can not imagine. But this cannot form the basis of an argument. Any argument against this list must be based on empirical (actually existing life) observations or on a priori reasoning (using the concepts). Thus, any imaginable biology will use the concepts listed here. There may exist life forms very different from what we know, and they will probably enrich the list and give rise to a sophistication of it.

${ }^{30}$ Kauffman 2000, cf. his concept of "adjacent possible" of a system, that is, the sum of states which at any time $t$ is at a distance of one chemical reaction from the actual state. Kauffman's adventurous idea (and candidate to a 4th law of thermodynamics) is that the biosphere invades this "adjacent possible" with maximum speed, thus at any instant covering more and more real possibilities.

${ }^{31}$ Hoffmeyer 2001a. 
bundle of merely possible actual objects later in a functional circle, ${ }^{32}$ that is, to a possibility, sometimes real, sometimes not.

\section{References}

Baldwin, James Mark 1902. Development and Evolution. New York: MacMillan Company.

Deacon, Terrence 1997. The Symbolic Species. W.W.Norton \& Co.

Emmeche, Claus; Kull, Kalevi; Stjernfelt, Frederik 2002. Reading Hoffmeyer, Rethinking Biology (Tartu Semiotics Library 3). Tartu: Tartu University Press.

Gould, Stephen Jay 1972. Punctuated equilibria: An alternative to phyletic gradualism. In: Schopf, T. J. M. (ed.), Models in Paleobiology. San Francisco: Freeman, Cooper \& Co., 82-115.

Hoffmeyer, Jesper 1992. Some semiotic aspects of the psycho-physical relation: The endo-exosemiotic boundary. In Sebeok, Umiker-Sebeok 1992: 101-123.

- 1996. Signs of Meaning in the Universe. Bloomington: Indiana University Press.

- 1997. The swarming body. In: Rauch, Irmengard; Carr, Gerald F. (eds.), Semiotics Around the World: Synthesis in Diversity. Proceedings of the Fifth Congress of the International Association for Semiotic Studies, Berkeley 1994. Berlin: Mouton de Gruyter, 937-940.

- 1998. Surfaces inside surfaces: On the origin of agency and life. Cybernetics and Human Knowing 5(1): 33-42.

- 1998a. Semiosis and biohistory: A reply. Semiotica 120(3/4): 455-484.

- 1999. Order out of indeterminacy. Semiotica 127(1/4): 321-343.

- 2001. Semiogen afstivning i naturen [Semiogenic scaffolding in nature]. In Thellefsen, T. (ed.), Tegn og betydning. Copenhagen: Akademisk, 124-143.

— 2001a. Seeing virtuality in nature. Semiotica 134(1/4): 381-398.

- 2001b. S/E > 1: A semiotic understanding of bioengineering. Sign Systems Studies 29(1): 277-292.

- 2002. Biosemiosis som Årsagskategori [Biosemiosis as causal category]. Kritik 155/156 (in press).

Hoffmeyer, Jesper; Emmeche, Claus 1991. Code-duality and the semiotics of nature. In: Anderson, Myrdene; Merrell, Floyd (eds.), On Semiotic Modeling. Berlin: Mouton de Gruyter, 117-166.

${ }^{32}$ In a broad sense, thus, any segment of a functional circle could be said to be a sign for any other segment of the same circle. What makes us speak of signs specifically, though, is probably the fact that some small segments have acquired stability so that they may repeatedly propagate the same form (René Thom: signs as propagators of form). A gene is a sign because it may repeatedly be read by the RNA; sugar is a sign for Escherichia coli because it repeatedly reacts in similar ways to it. The sign is thus: small (in comparison to its signification, the process which it informs), stable (in comparison to the process reading it). 


\section{Frederik Stjernfelt}

Husserl, Edmund 1980 [1901/1921]. Logische Untersuchungen. Tübingen: Max Niemeyer.

- 1993 [1937]. Das Gesetz der Fortpflanzung. In: Die Krisis. Ergänzungsband. (Husserliana vol. XXIX.) Dordrecht: Kluwer, 317-320.

Kauffman, Stuart 2000. Investigations. Oxford: Oxford University Press.

Kull, Kalevi 1999. Biosemiotics in the twentieth century: A view from biology. Semiotica 127(1/4): 385-414.

Peirce, Charles S. 1934-1958. Collected Papers, vol. I-VIII (Hartshorne \& Weiss; Burks, eds.). Princeton: Harvard University Press.

- 1976. The New Elements of Mathematics, vol. I-IV (Eisele, C., ed.), The Hague etc.: Mouton.

Petitot, J. 1992. Physique du sens. Paris: Éditions du CNRS.

Prodi, Giorgio 1988. Signs and codes in immunology. In: Sercarz, Eli E.; Celada, Franco; Mitchison, N. Avrion; Tada, Tomio (eds.), The Semiotics of Cellular Communication in the Immune System. Berlin: Springer, 53-64.

Sebeok, Thomas A. 1991. A Sign is Just a Sign. Bloomington: Indiana University Press.

- 1991a. American Signatures: Semiotic Inquiry and Method. Norman: Univ. of Oklahoma Press.

- 1992. 'Tell me, where is fancy bred?': The biosemiotic self. In: Sebeok, Umiker-Sebeok 1992: 333-343.

- 2001. Global Semiotics. Bloomington: Indiana University Press.

Sebeok, Thomas A.; Umiker-Sebeok, Jean (eds.) 1992. Biosemiotics: The Semiotic Web 1991. Berlin: Mouton de Gruyter.

Smith, Barry 1996. In defense of extreme (fallibilistic) apriorism. Journal of Libertarian Studies 12: 179-192.

- 1998a. Casati, Roberto; Smith, Barry; Varzi, Achille C. 1998. Ontological tools for geographic representation. In: Guarino, Nicola (ed.), Formal Ontology in Information Systems. Amsterdam: IOS Press, 77-85.

- 1998b. Ontologie des Mesokosmos: Soziale Objekte und Umwelten. Zeitschrift für philosophische Forschung 52: 521-540.

- 2001. Objects and their environments: From Aristotle to ecological ontology. In: Frank, Andrew U.; Raper, Jonathan; Cheylan, Jean-Paul (eds.), Life and Motion of Socio-Economic Units. London: Taylor \& Francis.

Stjernfelt, Frederik 1992. Categorical perception as a general prerequisite to the formation of signs? On the biological range of a deep semiotic problem in Hjelmslev's as well as Peirce's semiotics. In: Sebeok, Umiker-Sebeok 1992: 427-454.

- 1999. Biosemiotics and formal ontology. Semiotica 127(1/4): 537-566.

- 2000. How to learn more: An apology for a strong concept of iconicity. In: Johansson, T. D.; Skov, Martin; Brogaard, Berit (eds.), Iconicity: A Fundamental Problem in Semiotics. Copenhagen: NSU Press, 21-58.

- 2000a. Diagrams as centerpiece of a Peircean epistemology. Transactions of the Charles S. Peirce Society 36(3): 357-384.

— 2000b. Mereology and semiotics. Sign Systems Studies 28: 73-98. 
- 2001. A natural symphony: The actuality of Uexküll's Bedeutungslehre for our days' semiotics. Semiotica 134(1/4): 79-102.

- 2001a. Biology, abstraction, schemata. In: Brogaard, Berit; Smith, Barry (eds.), Rationality and Irrationality, Vienna: Hölder-Pichler, 341-361.

- 2002. Categories, diagrams, schemata. In: Stjernfelt, Frederik; Zahavi, Dan (eds.), 100 Years of Phenomenology: Logical Investigations Revisited (in press).

- 2002a. Umberception and Econicity. Review of Umberto Eco's Kant and the Platypus. In: RS/SI, Toronto (2001, in press).

- 2002b. Die Vermittlung von Anschauung und Denken: Semiotik und Schematismus bei Kant, Cassirer und Peirce. Zeitschrift für Semiotik (in press).

- 2002c. Sebeotics at the threshold: Review of Ponzio and Petrilli 'Tom Sebeok'. Semiotica (in press).

Swenson, R. 1999. Epistemic ordering and the development of space-time. Semiotica 127(1/4): 567-597.

Thom, R. 1972. Stabilité structurale et morphogénese. Paris: Ediscience. [English version 1977, Structural Stability and Morphogenesis. Reading: Benjamin.]

- 1989. Causality and finality in theoretical biology: A possible picture. In: Casti, John; Karlqvist, Anders (eds.), Newton to Aristotle: Towards a Theory of Models for Living Systems. Boston: Birkhäuser, 39-45.

Tønnessen, Morten 2001. Outline of an Uexküllian bio-ontology. Sign Systems Studies 29(2): 683-691.

Uexküll, Jakob von 1982. The theory of meaning. Semiotica 42(1): 25-82.

\section{Tractatus Hoffmeyerensis: Biosemiootika väljendatuna 22 alushüpoteesi kaudu}

Artikkel esitab biosemiootika põhiideed 22 hüpoteesi kaudu, tuginedes eelkõige Jesper Hoffmeyeri töödele.

\section{Tractatus Hoffmeyerensis: Основы биосемиотики в 22 гипотезах}

Статья излагает основы биосемиотики в 22 основных гипотезах, которые опираются, в основном, на работы Еспера Хоффмейера. 